\title{
Rest Area di Perawang
}

\author{
M. Habbib Arifnur ${ }^{1}$, Imbardi $^{2}$, Sudarmin $^{3}$ \\ 1,2,3 Program Studi Arsitektur, Fakultas Teknik, Universitas Lancang Kuning Pekanbaru \\ Jl. Yos Sudarso km. 8 Rumbai, Pekanbaru, Telp. (0761) 52324) \\ Email: Arifnur515@gmail.com, imbardi@unilak.ac.id, sudarmin@unilak.ac.id
}

\begin{abstract}
ABSTRAK
Tempat istirahat atau dikenal secara lebih luas sebagai rest area adalah tempat beristirahat sejenak untuk melepaskan kelelahan, kejenuhan, ataupun ke toilet selama dalam perjalanan jarak jauh.Tempat istirahat ini banyak ditemukan di jalan tol ataupun dijalan nasional di mana para pengemudi jarak jauh beristirahat. Dijalan arteri primer juga banyak ditemukan restoran yang berfungsi sebagai tempat istirahat. Restoran-restoran ini banyak digunakan oleh pengemudi truk jarak jauh ataupun bus antar kota untuk beristirahat. Dalam peraturan perundangan mengenai Lalu Lintas dan Angkutan Jalan ada ketentuan yang menyebutkan bahwa setiap mengemudikan kendaraan selama 4 jam harus istirahat selama sekurang-kurangnya setengah jam, untuk melepaskan kelelahan, tidur sejenak ataupun untuk minum kopi, makan ataupun ke kamar kecil/toilet. Waktu kerja bagi Pengemudi Kendaraan Bermotor Umum paling lama 8 (delapan) jam sehari, sehingga tempat istirahat juga digunakan untuk tempat pergantian pengemudi.
\end{abstract}

Kata Kunci: Rest Area, Desain, Konsep Dasar Area Rest

\begin{abstract}
A resting place or more widely known as a rest area is a place to take a break to release fatigue, boredom, or to the toilet during long distance travel. This rest area is found on many toll roads or on national roads where long-distance drivers rest. The primary arteries are also found in restaurants that function as a resting place. These restaurants are widely used by long-distance truck drivers or inter-city buses to rest. In the legislation concerning Road Traffic and Transportation there are provisions which state that each driving a vehicle for 4 hours must rest for at least half an hour, to release fatigue, take a nap or for coffee, meals or toilet. Working time for General Motor Vehicle Driver is 8 (eight) hours a day, so that the resting place is also used for driver changeover.
\end{abstract}

Key word: Rest Area, Design, concept area rest

\section{PENDAHULUAN}

Pembangunan pariwisata merupakan kegiatan dan usaha yang terkoordinasi untuk menarik wisatawan, menyediakan semua prasarana dan sarana serta fasilitas yang diperlukan dalam melayani permintaan wisatawan. Pertumbuhan dan perkembangan pariwisata di Provinsi Riau dewasa ini mengindikasikan bahwa pariwisata telah menjadi sektor ekonomi utama tidak saja di Provinsi Riau juga bagi Indonesia. Perkembangan kepariwisataan di Provinsi Riau menunjukkan hasil yang menggembirakan. Hal ini bisa dilihat dari jumlah kunjungan wisatawan nusantara maupun mancanegara yang berkunjung ke Provinsi Riau dari tahun ketahun selalu menunjukkan peningkatan. Namun ini semua tergantung dengan kondisi di suatu daerah, semakin kondusif suatu daerah maka kemungkinan wisatawan untuk mengunjungi daerah tersebut akan semakin tinggi, namun sebaliknya jika kondisi daerah tidak kondusif maka wisatawan akan enggan untuk berkunjung ke daerah tersebut. 
Tujuan utama pengembangan industri pariwisata adalah untuk menggaet penerimaan devisa dari pengeluaran wisatawan yang mengunjungi suatu negara. Kalau devisa hasil ekspor diperoleh dari penjualan barang-barang di luar negeri, namun di sektor pariwisata devisa diperoleh dari pengeluaran wisatawan yang mengunjungi suatu negara.

Sekarang rest area telah berubah menjadi life style. Rest area yang tadinya hanya berfungsi untuk melepaskan kepenatan kala mengemudi telah berubah fungsi tidak hanya untuk melepas kantuk, tapi sudah berubah menjadi tempat belanja, cuci mata, dan sekedar untuk makan malam. Bagi pengunjung kota Perawang begitu juga halnya. Rest Area merupakan tempat relaks sejenak setelah lelah beraktivitas ataupun merupakan tempat berinteraksi sesama teman dan keluarga.

Rest Area yang ada saat ini kebanyakan berada di jalan tol terutama pada kota - kota besar di pulau Jawa sedangkan di pulau Sumatra sampai saat ini belum terdapat sebuah jalan tol termasuk di kota Perawang. Hotel yang merupakan tempat perisitirahatan di Perawang juga sudah banyak tetapi hotel atau tempat peristirahatan di tepian sungai Siak belum ada, pengunjung yang datang dari luar kota perawang untuk berwisata, bisnis, dagang, dan transit juga sangat ramai. Pengunjung yang datang selama beberapa hari tentu membutuhkan tempat istirahat atau menginap. Jarak antar kebupaten atau kota yang jauh juga juga memungkinkan pengunjung untuk menginap beberapa hari sambil memulihkan kembali tenaganya untuk kembali kedaerahnya. Tidak hanya itu Rest Area di tepian sungai juga di harapkan mampu mewadahi pegunjung dari transportasi darat maupun air yang ingin beristirahat sejenak. Dengan adanya pengunjung yang datang dari luar kota Perawang, Rest Area dapat berfungsi tempat istirahat sejenak dan berekrasi

\section{METODE PENELITIAN}

Metode yang digunakan untuk mendapatkan data-data yang terkait dengan perancangandan"Rest Area Perawang” ini adalah sebagai berikut:

\section{Studi Literatur}

Studi perpustakaan dengan menelaah bukubuku atau artikel yang berkaitan dengan data yang di butuhkan.

\section{Survey Banding}

Yaitu dengan mengumpulkan data serta referensi terkait dengan Rest Area. Melakukan peninjauan tempat - tempat sejenis dengan Rest Area baik secara langsung maupun tidak langsung, seperti melalui internet, artikel, majalah, dan sebagainya.

\section{HASIL PENELITIAN}

\section{Lokasi pada Tapak Rest Area Di Perawang}

Lokasi tapak berada di Jalan Pintas Pekanbaru-Perawang, Kecamatan Tualang Kota Perawang, di sekitar tapak terdapat bangunan pendukung seperti Pujisera/Cafe, Mini Market, SPBU, Thoilet, Musholla lokasi tapak luas $40.500 \mathrm{~m} 2$ 


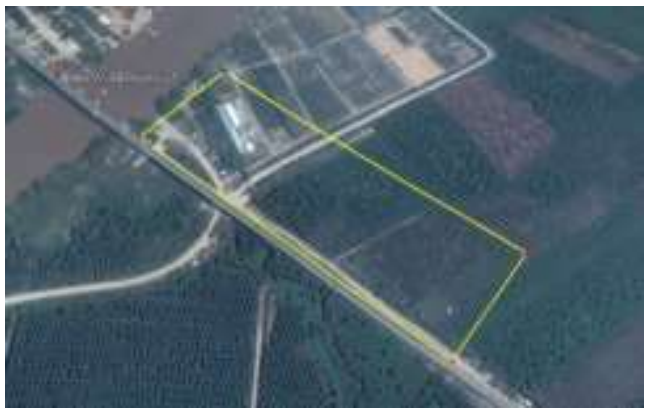

Gambar 1.Tapak Hotel Resort Wisata

\section{Kondisi Bangunan dan Lingkungan nya}

Dari survei lapangan ada beberapa bangunan dan lingkungan yang memerlukan fasilitas pendukung baik itu dari segi fasilitasnya maupun sarana dan prasarananya. Sehingga perlu dirancang Rest Area Di Perawang.

\section{Akses Jalan yang ada disekitar Tapak}

Untuk aksessibilitas/pencapaian dari luar sangat baik karena hanya ada satu akses masuk yaitu jembatan maredan.

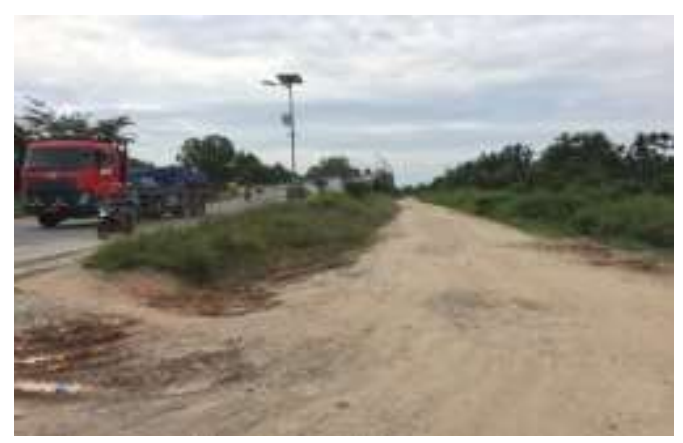

Gambar 2.Akses Jalan Masuk

\section{Kondisi Dalam Tapak}

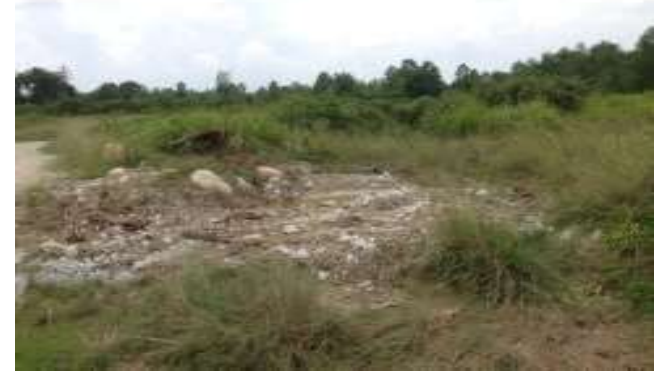

Gambar 3. Suasana didalam Tapak

\section{Bangunan disekitar Tapak}

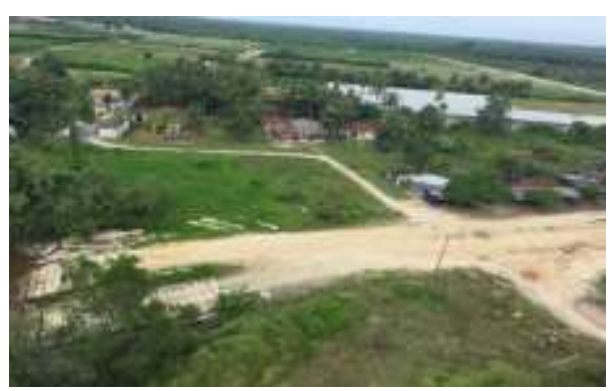

Gambar 4. Pemungkiman Warga

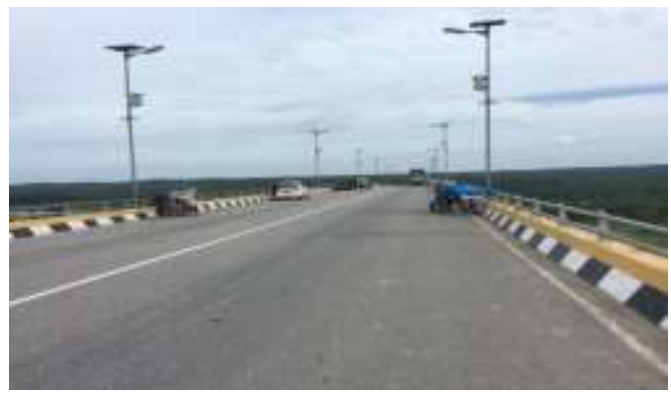

Gambar 5.Jembatan Maredan

\section{Aspek Manusia}

Analisa aspek manusia merupakan hal yang penting bagi seorang perancangan dalam merangcang sebuah bangunan ,karena manusia merupakan pengguna dari pada bangunan tersebut.Diharapkan perancang dapat merancang sesuai dengan kriteria dan kebutuhan manusai sebagai pengguna bangunan.

Faktor manusia sangat penting di perhatikan saat mendesain sebuah bangunan, hal ini sangat berpengaruh terhadap ruang-ruang yang akan kita butuhkan. Pada faktor manusia ini terdapat 3 aspek yang sangat penting, yaitu :

\section{Pelaku Kegiatan}

2.Aktivitas Pelaku

3.Kebutuhan Ruan).

\section{Analisa Pelaku Kegiatan}

Pelaku kegiatan yang ada pada bangunan "Rest Area Di Perawang" adalah sebagai berikut 
- Pengelola Rest Area

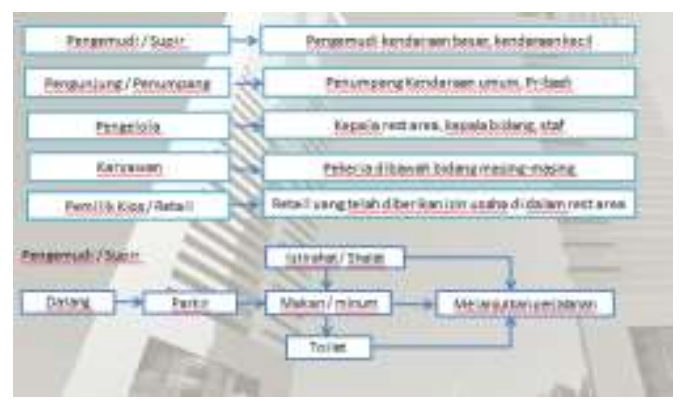

Skema 1. Alur kegiatan Hotel Resort

- $\quad$ Pengunjung Wisata

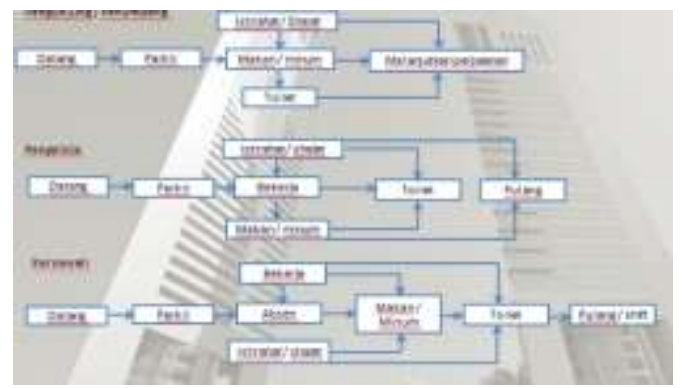

Skema 2. Alur kegiatan pengujung wisata

\section{Skema organisasi ruang makro}

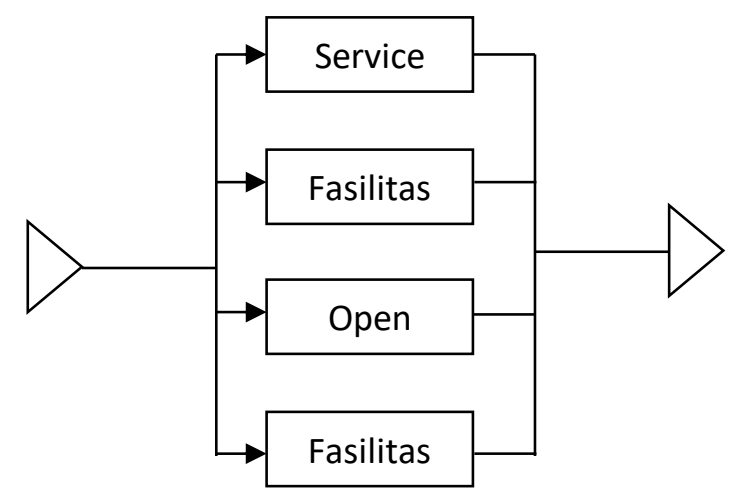

Skema 3.pola ruang makro

Fasilitas servis

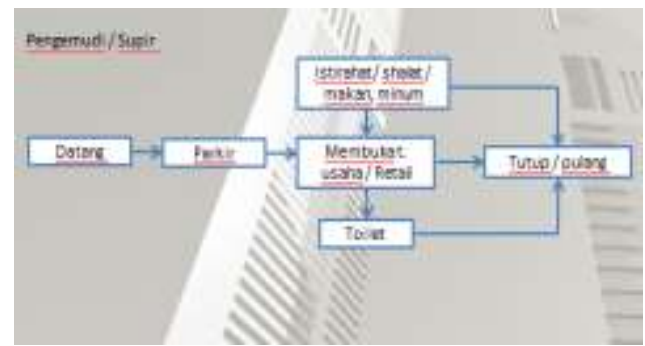

Skema 4.pola ruang mikro servis

\section{Analisa Tapak}

Lokasi Tapak Rest Area Di Perawang berada di Kecamatan Tualang Kota Perawang berada di jalan Pintas Pekanbaru-Perawang.

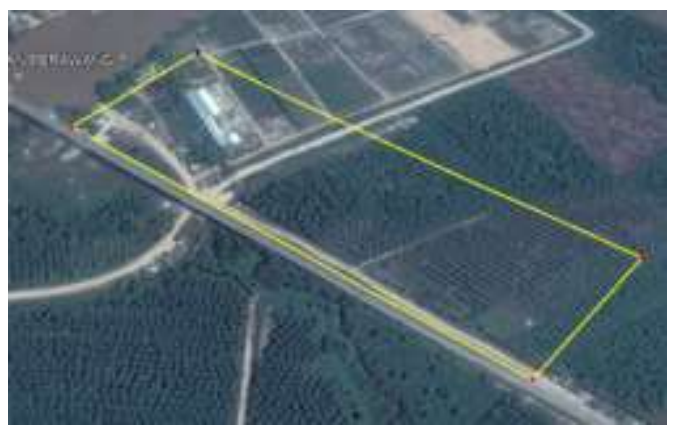

Gambar 6.Analisa Tapak

\section{Dimensi Tapak}

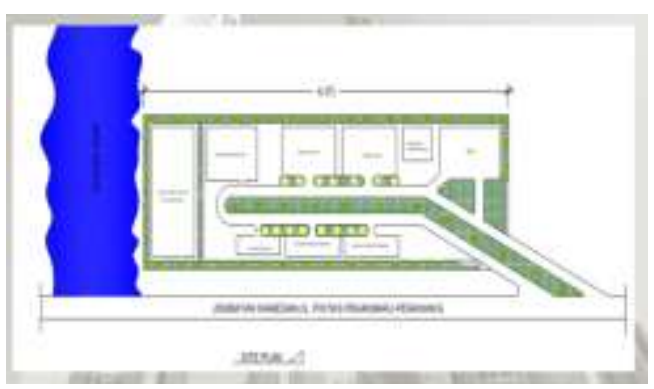

Gambar 7 : Dimensi Tapak

\section{Batas-Batas Dimensi Tapak}

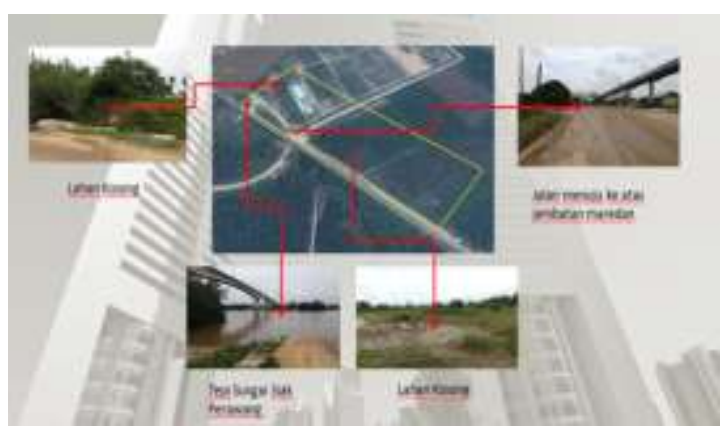

Gambar 8.Batas-Batas Tapak 


\section{Tapak Exsiting}

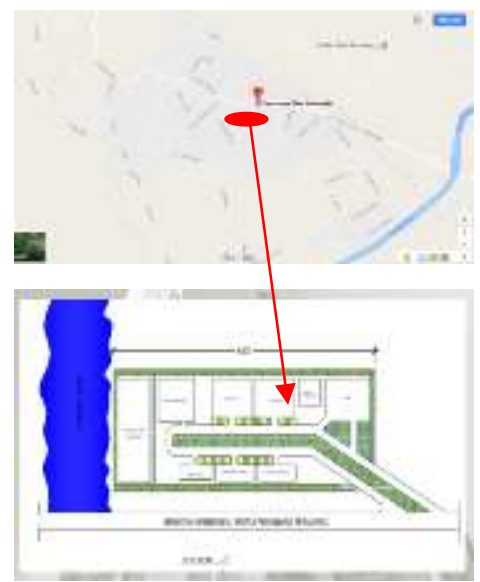

\section{Analisa dari luar kedalam tapak}

Pada gambar berikut merupakan suasana atau pendangan yang diambil dari view luar kedalam tapak.

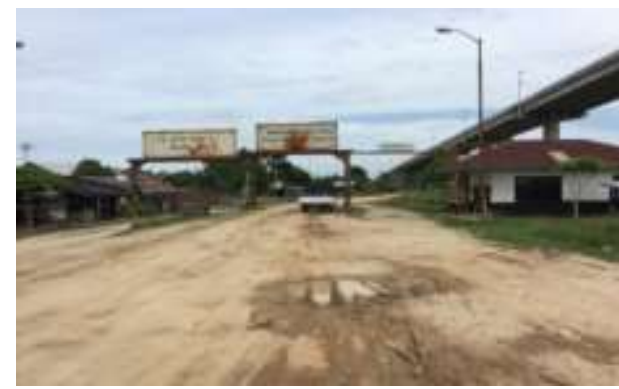

Gambar 9.Dari luar kedalam tapak

\section{Analisa Kondisi Tanah}

Perencanaan Rest Area Di Perawang dapat menjadi salah satu tempat Peristirahatan dan Rekreasi yang dapat dikunjungi dari luar kota perawang. Oleh karena lokasi terpilih berada di jalan pintas pekanbaru-perawang dibawah jembatan maredan .Kondisi tanah pada tapak yaitu:tanah pasir bulan.

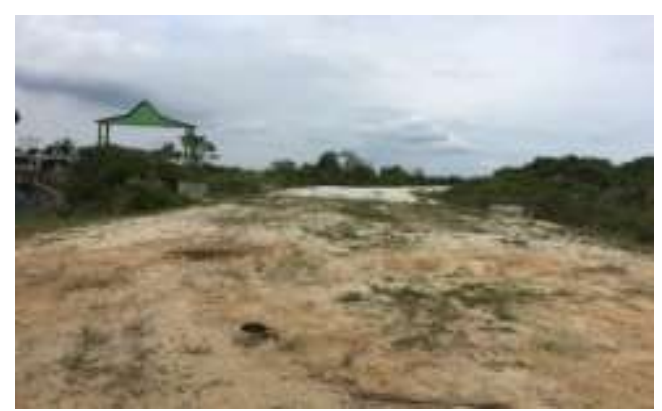

\section{Analisa Orientasi Matahari}

Dari analisa orientasi matahari terhadap tapak bahwasanya pengelompokan kegiatan-kegiatan yang nyaman terhadap kondisi tapak ialah berorientasi ke Timur karena mempertimbangkan bukaan terhadap sinar matahari pagi

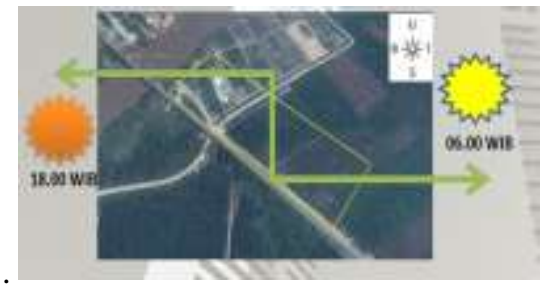

Gambar 11. Orientasi matahari

\section{Analisa Pencapaian dan Sirkulasi}

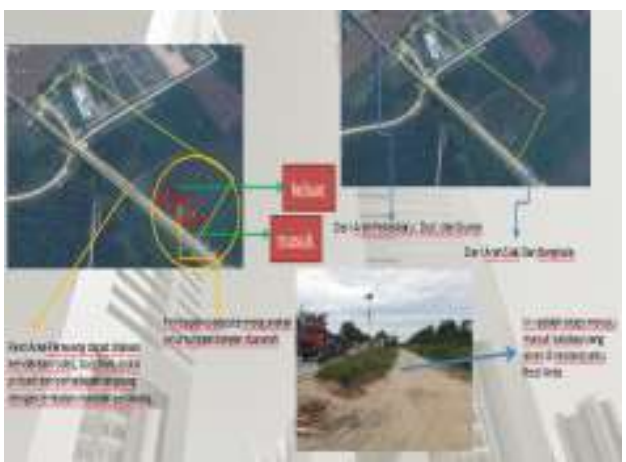

Gambar 12.Pencapaian

\section{Potensi}

Jalan menuju lokasi dilalui oleh kendaraan pribadi, bus, fuso, pick up dan kendaraan roda 2.

\section{Kendala}

1. Kemungkinan kemacetan yang diakibatkan di atas jembatan maredan disebabkan karena ada penjualan dan orang istirahat di atas jembatan maka diatasi dengan pembuatan rest area dibawah jembatan.

2. Intensitas kendaraan di perkirakan meningkat pada saat liburan dan hari-hari besar. Solusi

3. Perluasan area sirkulasi kendaraan menuju tapak agar tidak terjadi kemacetan dijembatan maredan akibat antrian kendaraan keluar-masuk tapak.

Gambar 10.Kondisi Tanah 


\section{Analisis Kebisingan}

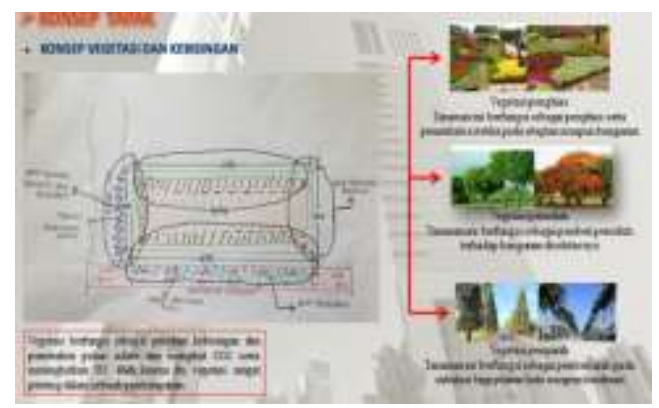

Gambar 13.Analisa view dan kebisingan

1. Kebisingan

Pada lokasi ini sumber kebisingan paling tinggi berada di jembatan maredan .Hal ini dikarenakan karena jalan tersebut merupan jalan Utama yang banyak dilalui oleh kendaraan.

Untuk mengurangi kebisingan akibat kendaraan besar, sebagai solusi desain dari halini maka di lakukan:

1. mempertahankan pohon dan tanaman peredu sebagai buffer hidup yang dapat mengurangi tingkat kebisingan sekaligus polusi udara.

2. Zoning ruang yang sensitif terhadap kebisingan di jahukan dari sumber kebisingan.

\section{Penzoning Tapak}

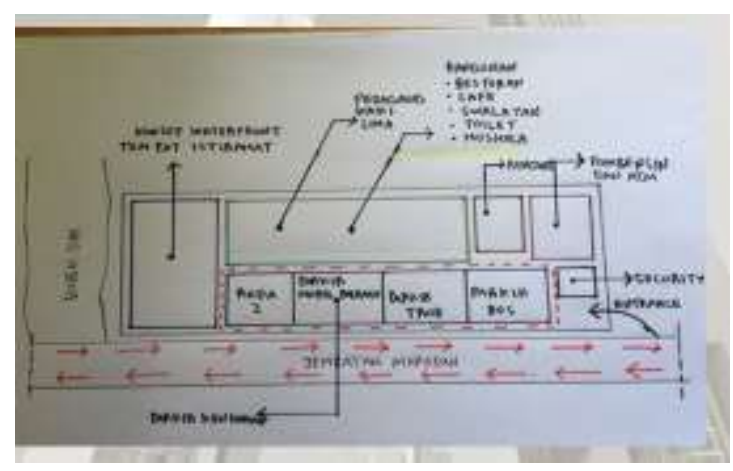

Gambar 14.penzoningan
Analisa Pemikiran Zoning Bangunan

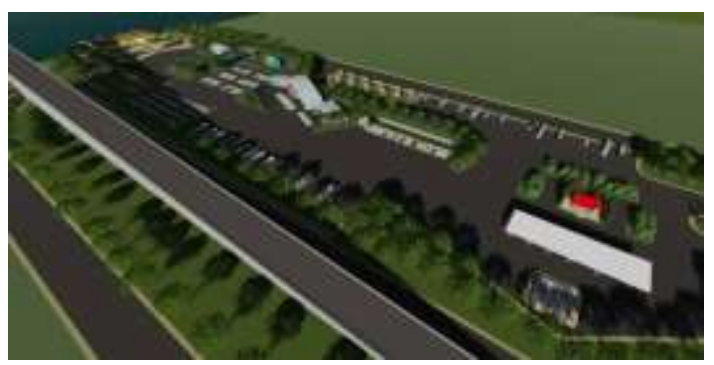

Gambar 15.Analisa pemikiran

Konsep zoning pada tapak berdasarkan pada Fungsi Masing-masing.Alur pembagian zoningnya berdasarkan fungsi agar pengorganisir zoning utama menghadapi sungai siak perawang dan jembatan maredan menjadi lebih jelas.

\section{Analisa Regulasi}

Adapun regulasi yang telah ditetapkan oleh pemerintah mengenai aturan antara lain : Kota pekanbaru berdasarkan RUTR (19912015) terbagi menjadi 5 wilayah pengembangan, yaitu: Wilayah Pengembangan (WP - I) terdiri dari kecamatan Tualng Kota, kel. Perawang.

\section{Analisa topik dan tema}

Topik : Waterfront

Tema : Pendekatan Rancangan Terhadap Arsitektur Ekologi

Analisis Rest Area Di Perawang berdasarkan tema yaitu pendekatan rancangan terhadap arsitektur ekologi.

Adapun Prinsif-prinsif Arsitektur Kontemporer itu sendi sebagai berikut :

A. Konsep bangunan terbagi 3 yaitu :

\section{A. Flutuation}

Prinsip fluktuasi menyatakan bahwa bangunan didisain dan dirasakan sebagai tempat membedakan budaya dan hubungan proses alami. Bangunan seharusnya mencerminkan hubungan proses alami yang terjadi di lokasi dan lebih dari pada itu membiarkan suatu proses dianggap sebagai proses dan bukan sebagai 
penyajian dari proses, lebihnya lagi akan berhasil dalam menghubungkan orang-orang dengan kenyataan pada lokasi tersebut.

\section{B. Stratification}

Prinsip stratifikasi menyatakan bahwa organisasi bangunan seharusnya muncul keluar dari interaksi perbedaan bagian-bagian dan tingkat-tingkat.Semacam organisasi yang membiarkan kompleksitas untuk diatur secara terpadu.

C. Interdependence (saling ketergantungan)

Menyatakan bahwa hubungan antara bangunan dengan bagiannya adalah hubungan timbal balik.Peninjau (perancang dan pemakai) seperti halnya lokasi tidak dapat dipisahkan dari bagian bangunan, saling ketergantungan antara bangunan dan bagian-bagiannya berkelanjutan sepanjang umur bangunan.

Eko arsitektur menonjolkan arsitektur yang berkualitas tinggi meskipun kualitas di bidang arsitektur sulit diukur dan ditentukan, takada garis batas yang jelas antara arsitektur yang bermutu tinggi dan arsitektur yang biasa saja.Fenomena yang ada adalah kualitas arsitektur yang hanya memperhatikan bentuk dan konstruksi gedung dan cenderung kurang memperhatikan kualitas hidup dan keinginan pemakainya, padahal mereka adalah tokoh utama yang jelas.

\section{Analisa Struktur}

Struktur bangunan adalah bagian dari sebuah sistem bangunan untuk memikul beban secara aman dan efektif, Beban yang bekerja pada bangunan serta menyalurkannya ke tanah melalui pondasi. Analisis struktur pada Rest Area Di Perawang adalah sebagai berikut:

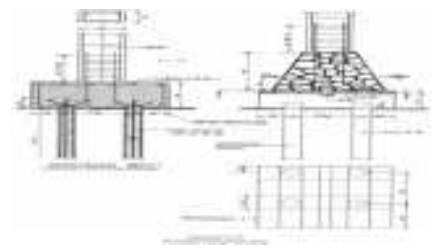

Gambar 16.pondasi tiang panvan

\section{Konsep Dasar Rest Area Di Perawang}

Konsep dasar "Rest Area Di Perawang" ini berlandaskan pada tema Arsitektur Ekologir, yaitu pendekatan terhadap arsitektur ekologi adalah keyakinan Sebuah konsep arsitektur yang berusaha meminimalkan pengaruh buruk terhadap lingkungan alam maupun manusia dan menghasilkan tempat hidup yang lebih baik dan lebih sehat, yang dilakukan dengan cara memanfaatkan sumber energi dan sumber daya alam secara efisien dan optimal. Arsitektur ekologi(eko-architecture) merupakan pembangunan berwawasan lingkungan ,dimana memanfaatkan potensi alam semaksimal mungkin. Eko arsitektur menonjolkan arsitektur yang berkualitas tinggi meskipun kualitas di bidang arsitektur sulit diukur dan ditentukan, takada garis batas yang jelas antara arsitektur yang bermutu tinggi dan arsitektur yang biasa saja.Fenomena yang ada adalah kualitas arsitektur yang hanya memperhatikan bentuk dan konstruksi gedung dan cenderung kurang memperhatikan kualitas hidup

\section{Konsep Zoning Tapak}

Konsep Penzoningan Pada Tapak Berdasarkan analisa ada 12 zoning perancang, penempatan zona-zona pada tapak di pertimbangkan berdasarkan 


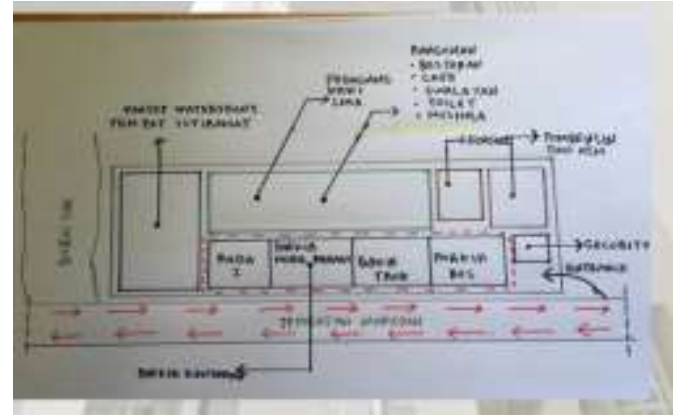

Gambar 17. Konsep zoning Tapak

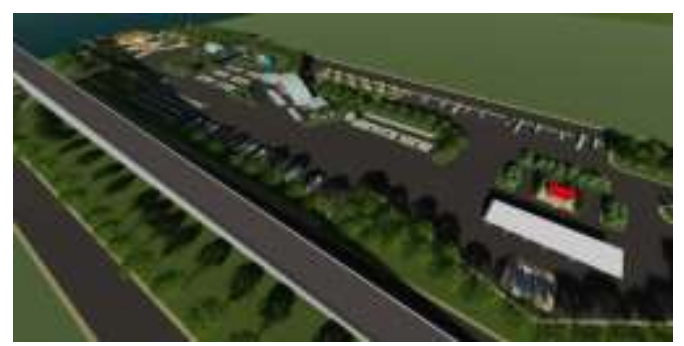

Gambar18.Konsep zoning kegiatan

Konsep zoning pada tapak berdasarkan pada Fungsi Masing-masing.Alur pembagian zoningnya berdasarkan fungsi agar pengorganisir zoning utama menjadi lebih jelas mengarakan kedepan sungai siak perawang.

\section{Konsep Sirkulasi}

Dalam konsep sirkulasi pada Rest Area Di Perawang ini di bagi menjadi 2 bagian yaitu :

1. Ruang Luar Aktif adalah ruang luar yang menampung kegiatan manusia meliputi parkir dan sirkulasi kendaraan. adapun bentuk sirkulasi parkir yang digunakan ialah parkir sudut $45^{\circ} / 90^{\circ}$.

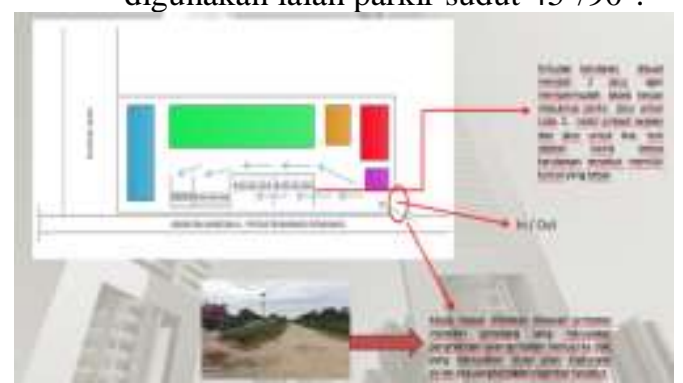

Gambar 19. Konsep Sirkulasi parkir

Konsep sirkulasi parkir untuk kendaraan roda empat, Fuso, bus dan roda dua di pisah agar mempermudah aktifitas kendaraan untuk masuk menuju kedalam tapak maupun ke luar tapak dan tidak menganggu aktifitas di luar tapak.

\section{Konsep kebisingan}

Konsep kebisingan pada tapak yaitu untuk menangani kebisingan mengunakan penerapan sistem vegetasi yang difungsikan sebagai peneduh dan menetralisir kebisingan dan sebagai penyerap udara.

Dari jalan Limbungan tingkat kebisingan yang paling tinggi berada pada Nomor 1 dan Sedangkan tingkat kebisingan yang sedang yaitu berada pada Nomor 2 dikarenakan jalan menuju kedalam tapak cuma memilik 1 akses jalur masuk dan jalur keluar dari jembatan maredan.

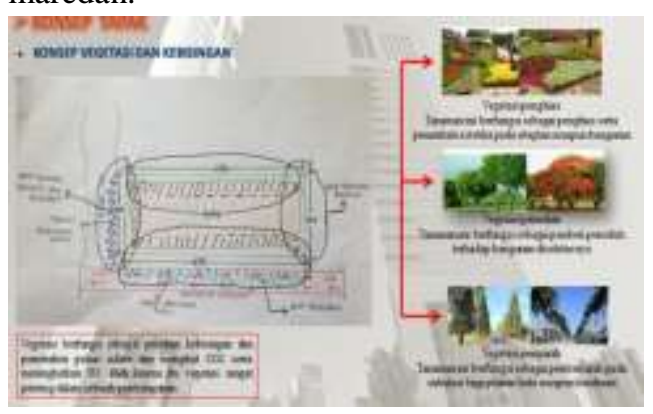

Gambar 21. Konsep kebisingan

\section{Konsep Vegetasi}

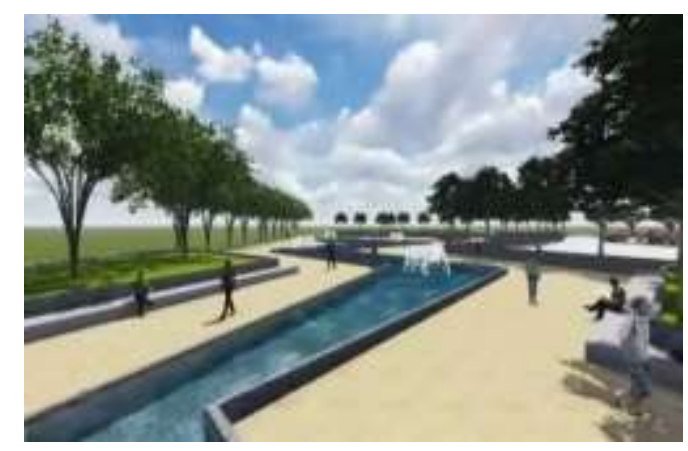

Gambar 22. Konsep Vegetasi

Jenis Vegetasi ada 3 sebagian berikut ini:

\section{Vegetasi penghias \\ 2.Vegetasi peneduh 3.Vegetasi pengarah}




\section{Konsep Masa Bangunan}

Konsep masa bangunan pada Rest Area Di Perawang ini lebih mendekatkan kepada proses atau tahapan - tahapan dalam program melalui pendekatan tampil dan bentuk mengikuti tapak pada bangunan.

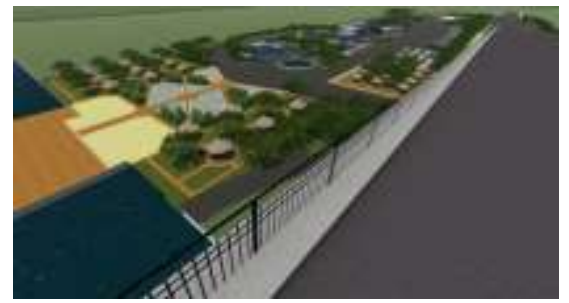

Gambar 23. Konsep Masa Bangunan

\section{Konsep Gubahan Masa Bangunan}

Konsep gubahan masa bangunan yang diterapkan adalah bentuk yang disesuaikan dengan karakter tapak dengan pertimbangan pemanfaatan kontur, orientasi matahari, view danau, vegetasi disesuaikan dengan konsep dasar pembangunan .

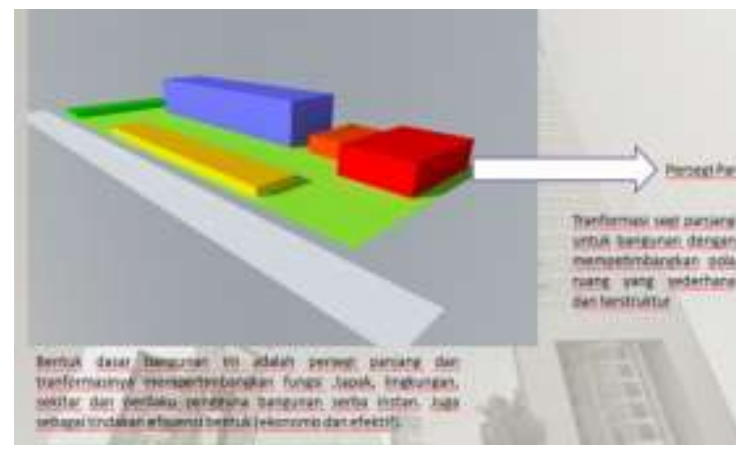

Gambar 24. Konsep Gubahan Masa Bangunan

\section{Hasil Perancangan Hotel Resort Wisata}

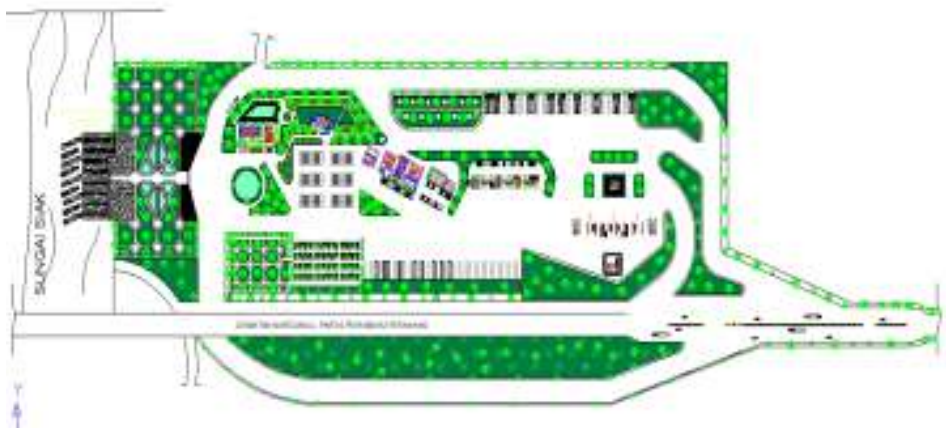

Gambar 25. Site Plan Hotel Resort Wisata
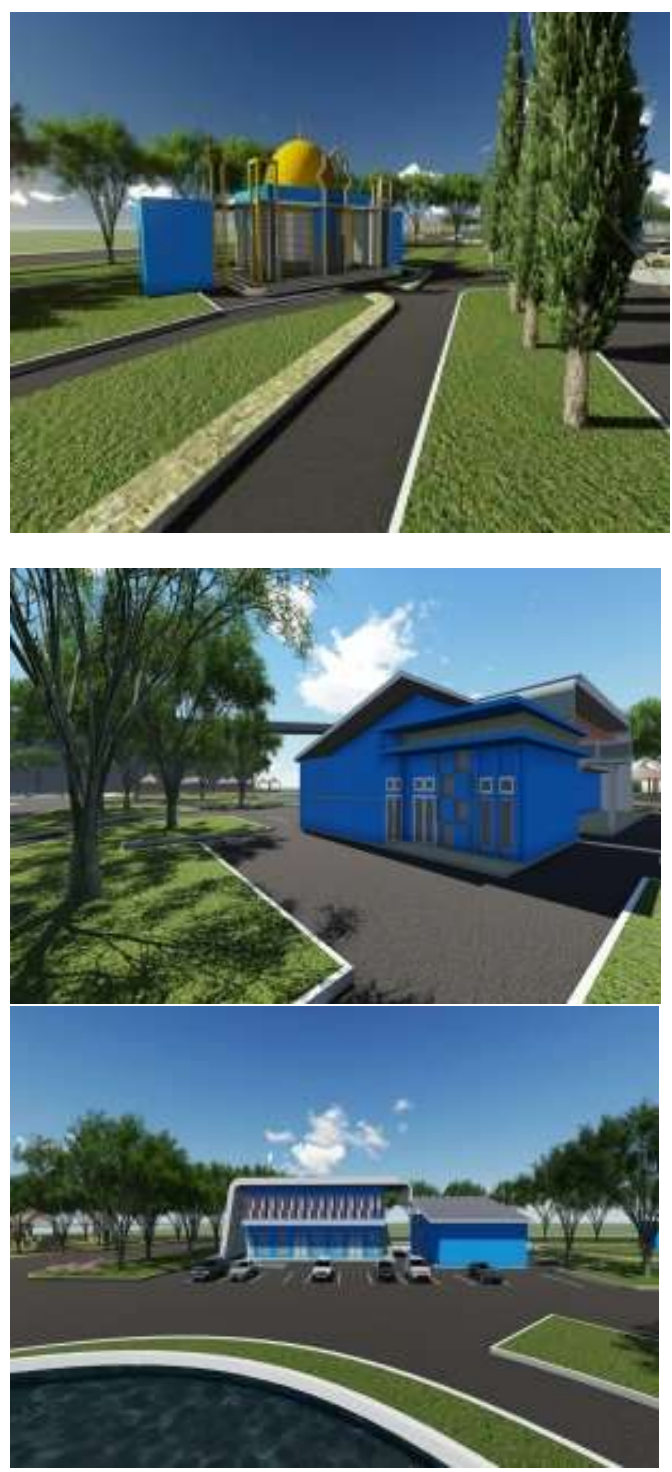

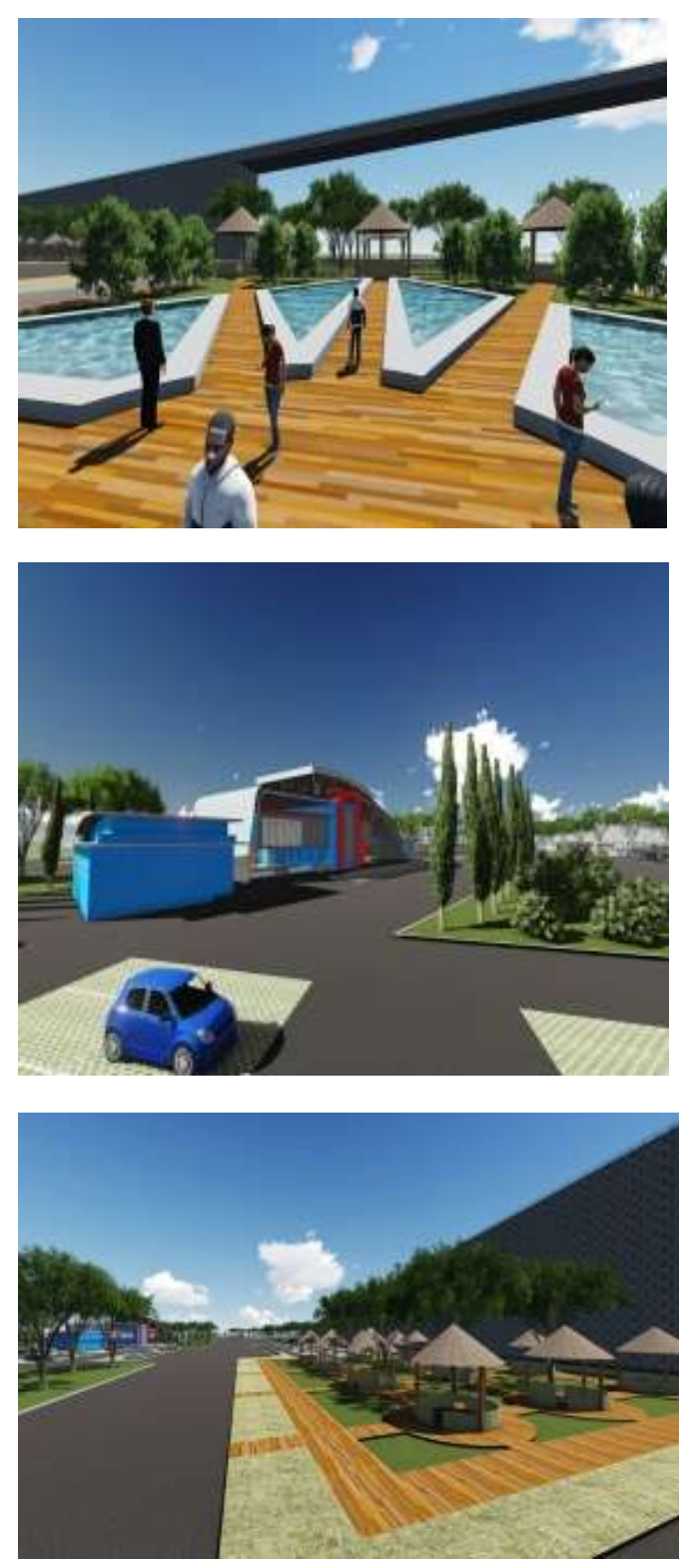

Gambar 26. Perspektif Hotel Resort Wisata

\section{KESIMPULAN DAN SARAN}

Rest area yang tadinya hanya berfungsi untuk melepaskan kepenatan kala mengemudi telah berubah fungsi tidak hanya untuk melepas kantuk, tapi sudah berubah menjadi tempat belanja, cuci mata, dan sekedar untuk makan malam. Bagi pengunjung kota Perawang begitu juga halnya. Rest Area merupakan tempat relaks sejenak setelah lelah beraktivitas ataupun merupakan tempat berinteraksi sesama teman dan keluarga.

Besar harapan dalam "rest area di perawang" ini adalah untuk dapat mewadahi kegiatan yang berkaitan dengan wisatawan sebagai tempat penginapan dan rekreasi hiburan untuk masyarakat kota perawang sendiri.

\section{DAFTAR PUSTAKA}

[1] Ching,D.K, Francis dan Cassandra Adams, 1985, Ilustrasi Kontrusksi Bangunan, Penerbit Erlangga

[2] Ching,D.K, Francis.1985, Arsitektur:Bentuk-Ruang dan Tatanan, Jakarta : Erlangga

[3] Frick Ch. Koesmartadi, Heins, Ilmu Bahan Bangunan, Eksploitasi, Pembuatan, Penggunaan Dan Pembuangan. Penerbit Kanisius

[4] Geord, Lippsmeier, Bangunan Tropis

Neufert, Ernest, 1996, Data Arsitek JILID 1 Edisi 33. Penerbit Erlangga, Jakarta

Neufert, Ernest, 2002, Data Arsitek JILID 2 Edisi 33. Penerbit Erlangga, Jakarta

[5] Peraturan Daerah Provinsi Riau, Tentang Perlindungan dan Pemberdayaan Penyandang Dissabilitas No. 18 Tahun 2013, Pekanbaru: Dinas Sosial

[6] Todd, W. Kim, Tapak,Ruang, dan Struktur. Bandung: Intermatra. Ing. Y. B. Mangunwijaya, Dpil, Pengantar Fisika Bangunan. Penerbit Djambatan

[7] Rahmanto, Abdul, 2016, Tugas Akhir: Pusat Rehabilitasi Ketergantungan Narkoba Di Pekanbaru, Pekanbaru

https://www.google.co.idgws_rd=cr,ssl\&ei =P7IPWLPmJ4vzvgSmgYv4Bg\#q=prevale $\underline{\text { nsi+disabilitas+di+riau, Diakses tanggal } 05}$ Agustus 2016

[8] Peraturan menteri pekerjaan umum Nomor: 30/prt/m/2006, Diakses tanggal 21 Februari 2017 